\title{
Removal of Vanadium from Molten Aluminum-Part III. Analysis of Industrial Boron Treatment Practice
}

\author{
ABDUL KHALIQ, MUHAMMAD AKBAR RHAMDHANI, GEOFFREY A. BROOKS, \\ and JOHN GRANDFIELD
}

\begin{abstract}
Transition metal impurities $(\mathrm{V}, \mathrm{Ti}, \mathrm{Zr}$, and $\mathrm{Cr}$ ) reduce the electrical conductivity of smelter grade aluminum. These impurities are removed in the form of their borides by reacting with added Al-B master alloys i.e., boron treatment. Although, boron treatment is widely used for the production of high purity aluminum alloys in casthouse the fundamental understanding is lacking and published industrial data are limited. In the current study, industrial trials on the removal of impurities were conducted at one of the high purity aluminum alloys producers in Australasia. Kinetics analysis revealed that the rate of reaction is controlled by the mass transfer of impurities in the bulk melt. The measured mass transfer coefficient $\left(k_{\mathrm{m}}\right)$ of $\mathrm{V}$ and Ti were $1.1 \times 10^{-4}$ and $2.6 \times 10^{-4} \mathrm{~m} / \mathrm{s}$ respectively, in the naturally stirred molten aluminum. The rate of $\mathrm{V}$ and $\mathrm{Ti}$ removal was faster compared to $\mathrm{Zr}$ and $\mathrm{Cr}$ during the boron treatment of smelter grade aluminum. Mass balance analysis revealed that $70 \mathrm{wt}$ pct of $\mathrm{V}$ and $\mathrm{Ti}$ combined as borides in the first hour of the total 12 hours of boron treatment process. The calculated amount of un-reacted B was approximately $25.5 \mathrm{wt}$ pct of initial amount added that remained in the final alloy. There was no evidence of boride rings formation, although partially dissolved $\mathrm{AlB}_{12}$ particles were observed under scanning electron microscope. Finally, implications for industrial practice are discussed for the improvement of current boron treatment process that include changing the source of boron, multiple stage addition of boron and better stirring of the molten aluminum.
\end{abstract}

DOI: $10.1007 / \mathrm{s} 11663-013-0017-4$

(C) The Minerals, Metals \& Materials Society and ASM International 2014

\section{INTRODUCTION}

SMELTER grade aluminum is used for electrical grade applications after the removal of transition metal impurities such as vanadium (V), titanium (Ti), zirconium $(\mathrm{Zr})$, and chromium $(\mathrm{Cr})$ which reduce the electrical conductivity of aluminum when present in solution. ${ }^{[1,2]}$ Transition metal impurities in the potline metal come from raw materials (alumina and coke) used in the Hall-Heroult process. ${ }^{[3-5]}$ Impurities dissolved in the solution with aluminum tend to reduce the electrical conductivity by electron scattering via thermal vibration of the crystal lattice. ${ }^{[6]}$ Vanadium and chromium have the greatest effect on resistivity, and the presence of these elements in the solution increases the resistivity by a factor of 10 to 20 .

Industrially, impurities such as $\mathrm{V}, \mathrm{Ti}, \mathrm{Zr}$, and $\mathrm{Cr}$ are removed in casthouse by the addition of boron bearing substances to the molten aluminum, known as boron

\footnotetext{
ABDUL KHALIQ, Post-doctoral Fellow, MUHAMMAD AKBAR RHAMDHANI, Director of Pathways, and GEOFFREY A. BROOKS, Professor, are with the Faculty of Engineering and Industrial Sciences, Swinburne University of Technology, Melbourne, VIC 3122, Australia. Contact e-mail: akhaliq@swin.edu.au JOHN GRANDFIELD, Adjunct Professor, is with the Faculty of Engineering and Industrial Sciences, Swinburne University of Technology, and also Director with the Grandfield Technologies Pty Ltd., Brunswick, VIC 3055, Australia.

Manuscript submitted September 8, 2013.

Article published online January 18, 2014.
}

treatment. ${ }^{[6-16]}$ In the boron treatment of molten aluminum, Al-B master alloys are added in the form of waffles, ingots, or rods, depending on the process requirement and the required quality of the end product. $\mathrm{Al}-\mathrm{B}$ master alloys containing $\mathrm{AlB}_{2}$ or $\mathrm{AlB}_{12}$ phases are commonly used in the industry. Impurities such as $\mathrm{V}$, $\mathrm{Ti}$, $\mathrm{Zr}$, and $\mathrm{Cr}$ combine with $\mathrm{B}$ and form their borides. The borides of transition metal impurities are stable and do not dissolve back into the melt once they form during the boron treatment of molten aluminum. ${ }^{[17]}$ The heavy borides formed during boron treatment are separated primarily using gravity settling or downstream filters. ${ }^{[7]}$ Boride settling time can be many hours depending on the desired purity of the final aluminum alloy.

There have been a number of studies on the removal of transition metal impurities from molten aluminum both in laboratory and industrial scales. Most of the laboratory studies focused on the increase of electrical conductivity by the addition of Al-B master alloys in molten aluminum..$^{[1,2,9-11,16,18]}$ Process industrial trials focused on the use of $\mathrm{AlB}_{12}$ or $\mathrm{AlB}_{2}$ and the increase in electrical conductivity with reaction time. ${ }^{[6,8,12]}$ Limited information is available regarding the kinetics and mass balance analysis of impurities during industrial boron treatment practices. To the author's knowledge, there is also no standard industrial procedure for the removal of vanadium and other transition metal impurities from smelter grade aluminum. Electrical grade aluminum manufacturers develop their own in-house practices for 
the boron treatment of smelter grade aluminum depending on their working capabilities and available facilities.

It has already been reported in literature that the level of $\mathrm{V}$ is increasing in the smelter grade aluminum. ${ }^{[19-21]}$ Various researchers have also reported the increase of $\mathrm{V}$ in petroleum coke and its impact on the final properties of aluminum. ${ }^{[19,22-24]}$ Many aluminum smelters are facing challenges due to the rise of impurities especially $\mathrm{V}$ in the petroleum coke. ${ }^{[4,5,21]}$ Keeping in view the increase of $\mathrm{V}$ and its high proportion in the smelter grade aluminum, the impurities analysis then the optimization of boron treatment is important to maintain the quality of electrical grade aluminum alloys. The investigation of $\mathrm{V}$ removal from molten aluminum is, therefore, crucial if the quality of electrical grade aluminum is to improve, which is the major focus of current research.

In Part I of this series of papers, a detailed analysis of $\mathrm{VB}_{2}$ formation in molten aluminum has been presented through thermodynamic modeling and experimental studies. ${ }^{[25]}$ Part II describes the kinetics analysis and the mechanism of $\mathrm{VB}_{2}$ boride formation in molten aluminum. ${ }^{[26]}$ In Part III (this paper), a critical analysis of industrial boron treatment was carried out. The boron treatment trials were performed at one of the main electrical grade aluminum producers in Australasia. The principle aim of this study is to obtain a better understanding of current boron treatment practice, and to identify opportunities for the improvement of current process. The kinetics and mass balance analysis of impurities such as vanadium and titanium, and boron are also analyzed in this article. The effect of gas stirring on the kinetics of vanadium removal from molten aluminum is also evaluated in this paper. Implications to the aluminum industries that produce electrical grade $\mathrm{Al}$ are also discussed based on the critical analysis of the results from industrial and laboratory trials.

\section{INDUSTRIAL BORON TREATMENT PRACTICE}

\section{A. Materials (Aluminum Borides)}

Primary aluminum, produced using reduction cell technology, is usually treated in-house for the removal of $\mathrm{V}$ and other transition metal impurities using Al-B master alloys (composed of $\mathrm{AlB}_{2}$ or $\mathrm{AlB}_{12}$ phases) in different forms such as rods, waffles, ingots, and wires. Commercial Al-B master alloys are usually produced having $3,4,5,6,8$, and $10 \mathrm{wt}$ pet boron, depending on the targeted intermediate phase in the aluminum matrix and process requirements. The analysis of different Al-B master alloys has been reported previously. ${ }^{[27]}$ In the current trials, an Al-8 wt pct B master alloy, containing $\mathrm{AlB}_{12}$, phase was used. The SEM image of the Al-B master alloy is shown in Figure 1. The particles of $\mathrm{AlB}_{12}$ are present in the form of clusters having polygonal shape. The particle sizes varied from 1 to $50 \mu \mathrm{m}$ and are shown as a black phase in a white aluminum matrix. The Al-B master alloy used was in the form of cast cut ingots having a cross section of $40 \mathrm{~mm} \times 30 \mathrm{~mm}, 1.1 \mathrm{~m}$ in

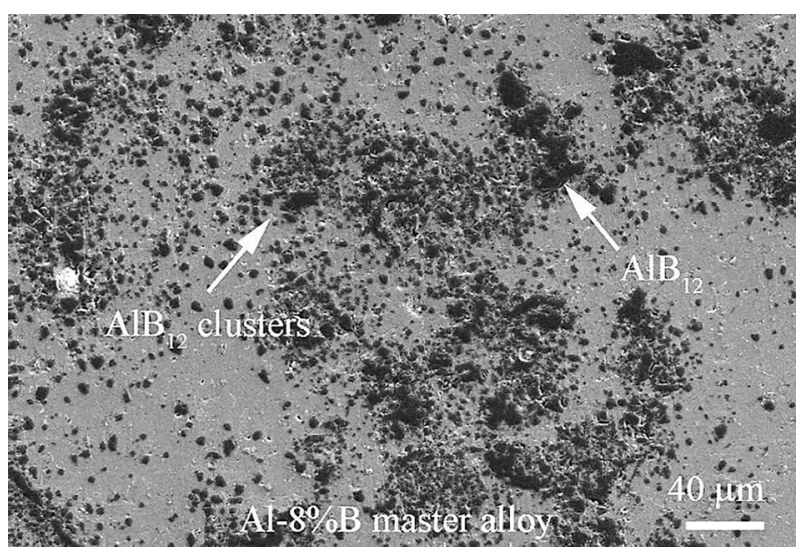

Fig. 1-SEM-SE image of Al-8 wt pct $\mathrm{B}\left(\mathrm{AlB}_{12}\right)$ master alloy used for the boron treatment.

length, and each weighed $3 \mathrm{~kg}$. The Al-B master alloy was obtained from London and Scandinavian Metallurgical (LSM) Co Limited, UK. In the current practice, boron was added based on the initial level of transition metals impurities measured during the early stage of the process. Further additions were made in the middle of the process, based on the quality requirements of the end product.

\section{B. Boron Treatment Practice}

The boron treatment of smelter grade aluminum was carried out in a 50 tons furnace. The schematic of the furnace from top view has been presented elsewhere. ${ }^{[27]}$ It was a gas fired furnace with three equally spaced burners fitted on one wall, which supply continuous heat to maintain a temperature of $1023 \mathrm{~K} \pm 15$ $\left(750 \pm 15^{\circ} \mathrm{C}\right)$ throughout the process. The furnace bath depth was approximately $2 \mathrm{~m}$ when filled with molten metal. Empty furnace was charged with the primary aluminum tapped from reduction cells using 5 tons crucibles. In the start of a heating process (filling empty furnace), in-house scrap was also charged in the furnace. At the smelters where trials were conducted, Al-B master alloys ingots were added at entrance spout of the furnace. Primary molten aluminum was introduced through the spout, which flushed Al-B master alloy to the furnace during pouring process. It is reasonable to assure that the Al-B master alloys were melted and $\mathrm{AlB}_{12} / \mathrm{AlB}_{2}$ particles dispersed in aluminum during the feeding of the second or third crucible in the furnace. The furnace fills in approximately 120 minutes and, on average, consumes 10 to 12 crucibles. Once the furnace was filled, stirring of the melt was carried out for 120 seconds with a long paddle using a forklift from the back door. The melt was stirred using a paddle attached to a forklift. The paddle was immersed at one side and the stirring was done by moving the paddle back and forth for 2 minutes. The melt was allowed to settle once the dross was skimmed from the top.

The details of both trials are summarized in Table I. After stirring and skimming, the melt was held for different periods, depending on the final level of purity required. To achieve a higher purity, the melt was held 
Table I. The Details of Events and Sampling During Industrial Trials

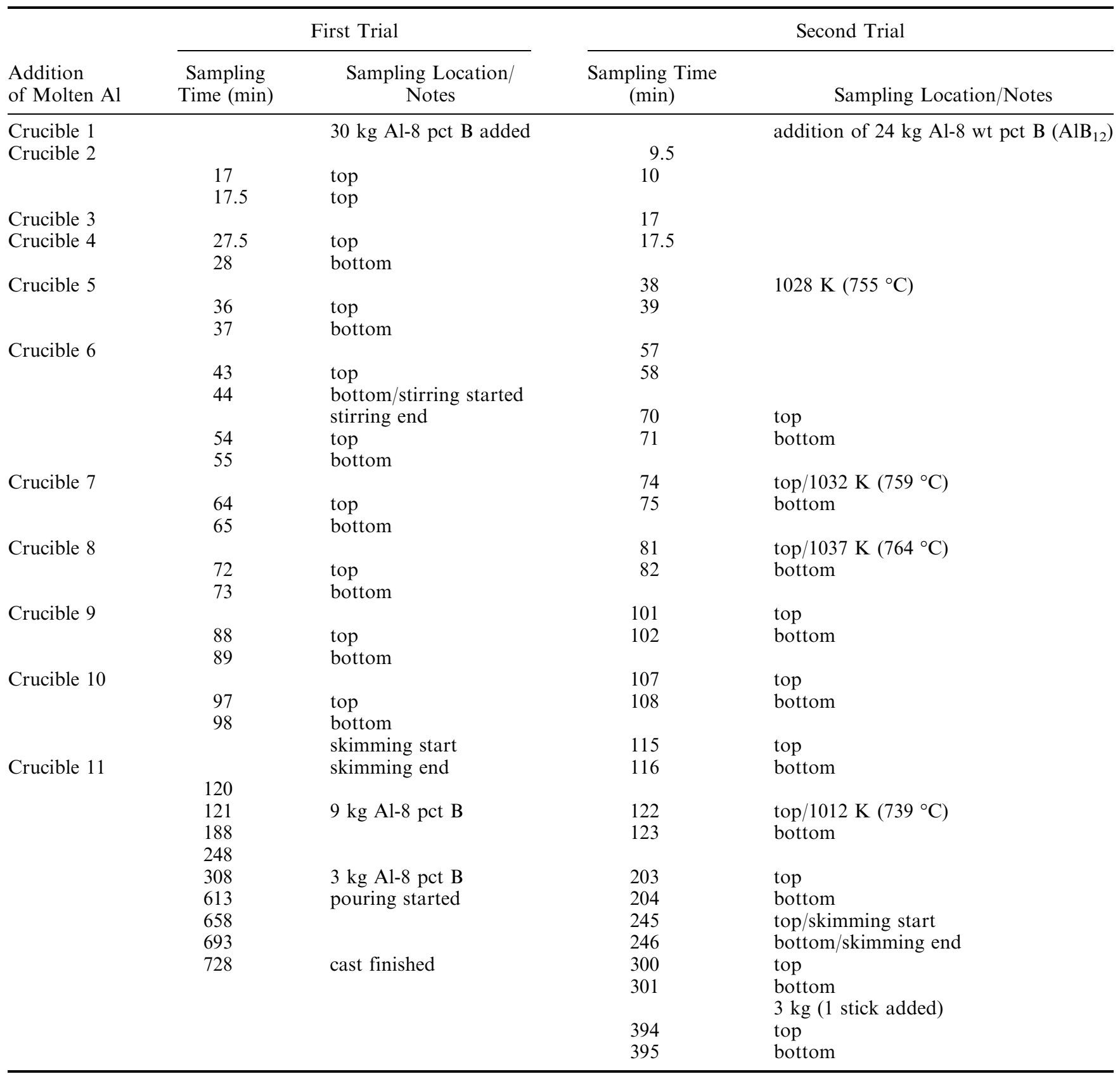

for longer as was practiced during the first trial. Prior to casting, the melt composition was analyzed again, and additional Al-B master alloy was introduced if required. The Al-B treated melt was held for 613 minutes (10.2 hours), followed by casting, which was completed in 115 minutes (1.9 hour). Comparatively, shorter melt holding was practiced for the second trial due to required purity of the final product.

\section{Sampling}

The sampling of melt was carried out using a $2.5 \mathrm{~m}$ long steel scoop. Two samples were taken each time, after the addition of single crucible into furnace. One sample was taken from just below the top of the melt and other from the bottom of furnace. The first sample was acquired just after the addition of first crucible (5 tons). The molten aluminum samples were cast into a standard spectrometer disks and allowed to solidify in air. Table I shows the timings of furnace charging with fresh molten crucibles, sampling practice, stirring, and skimming of molten aluminum during boron treatment trials.

\section{Samples Characterizations and Chemical Analysis}

The samples, taken at regular intervals during both trials were analyzed for the composition and morphology of borides. The chemical composition of the aluminum disk samples were analyzed using Spark Emission Spectroscopy technique. Selected disk samples 
were sectioned and prepared for microscopy (i.e., SEM and EDX) analysis. The sample preparation procedure was similar to that explained in Part I of this paper series. ${ }^{[25]}$ Microscopy analysis was carried out at Swinburne University of Technology, Melbourne. A SUPRA model 40VP-25-38 fitted with an energy dispersive X-ray spectrum (EDX) detector was used for the observation and identification of different phases.

For ICP-AES analysis, aluminum sample chips were prepared by drilling, followed by dissolution in $\mathrm{HCl}$ solution. The solution was then analyzed for the solute $\mathrm{V}$ contents in aluminum. It should be noted that the use of a 50 pet $\mathrm{HCl}$ acid solution allowed the dissolution of $\mathrm{Al}$ alloys along with solute $\mathrm{V}$, but leaving the $\mathrm{V}$ tied as $\mathrm{VB}_{2}$ in the filtrate. The use of $\mathrm{HNO}_{3}$ or $\mathrm{HF}$ acid with $\mathrm{HCl}$ will dissolve a small amount of $\mathrm{VB}_{2}$, as was reported by previous investigators ${ }^{[28]}$ thus was not used in the current study.

\section{RESULTS AND DISCUSSION}

\section{A. Kinetics of V Removal from Smelter Grade Aluminum}

The kinetics of $\mathrm{V}$ removal during first trial is shown in Figure 2(a). In this particular case, smelter grade (primary) aluminum contained $63 \mathrm{ppm} \mathrm{V}, 31 \mathrm{ppm} \mathrm{Ti}$, and 4 and ppm of both $\mathrm{Zr}$ and $\mathrm{Cr}$, respectively. It was observed that $\mathrm{V}$ constitutes 61 pct of all other transition impurities. Figure 2(a) shows the concentration of $\mathrm{V}$ decreased from 63 to $10 \mathrm{ppm}$ during boron treatment cycle of 740 minutes (12.33 hours). The observed trend of $\mathrm{V}$ concentration $v s$ time, as shown in Figure 2, is similar to the results from the laboratory studies. ${ }^{[25,26]}$ It is worth noticing that approximately 65 pct of $\mathrm{V}$ reacted during the first 100 minutes, i.e., the early stage of boron treatment process. The concentration of $\mathrm{V}$ dropped to $22 \mathrm{ppm}$ as the furnace was filled with primary metal. It was observed that the stirring of molten metal reduced with the passage of time that is the degree of mixing generated due to the addition of fresh molten aluminum decreased as the volume of melt increased in the furnace. The stirring of melt will help to homogenize the distribution of solid $\mathrm{AlB}_{12}$ particles and other transition impurities to form their borides. Stirring also increases the mass transfer coefficients of impurities that enhanced the reaction kinetics as previously reported. ${ }^{[26]}$

Larger drop in the concentration of $\mathrm{V}$ during the furnace filling stage was due to the fast reaction kinetics between $\mathrm{AlB}_{12}$ and $\mathrm{V}$ as explained previously. ${ }^{[25]}$ The chemical reaction kinetics of $\mathrm{V}$ and $\mathrm{B}$ was fast that produced $\mathrm{VB}_{2}$ within the first couple of minutes after the addition of Al-B master alloys into the aluminum melt. The kinetics of $\mathrm{V}$ removal from smelter grade aluminum and the concentration of $\mathrm{B}$ in the second trial are shown in Figure 2(b). Trends of $\mathrm{V}$ removal were similar to that shown in Figure 2(a). The required purity level was achieved with shorter holding time in the second trial that was completed in 395 minutes (6.6 hours). The V concentration dropped from $80 \mathrm{ppm}$ to $11 \mathrm{ppm}$ during the course of the melt treatment. Similar to the first trial, approximately 70 pct of the $\mathrm{V}$ was removed in the form

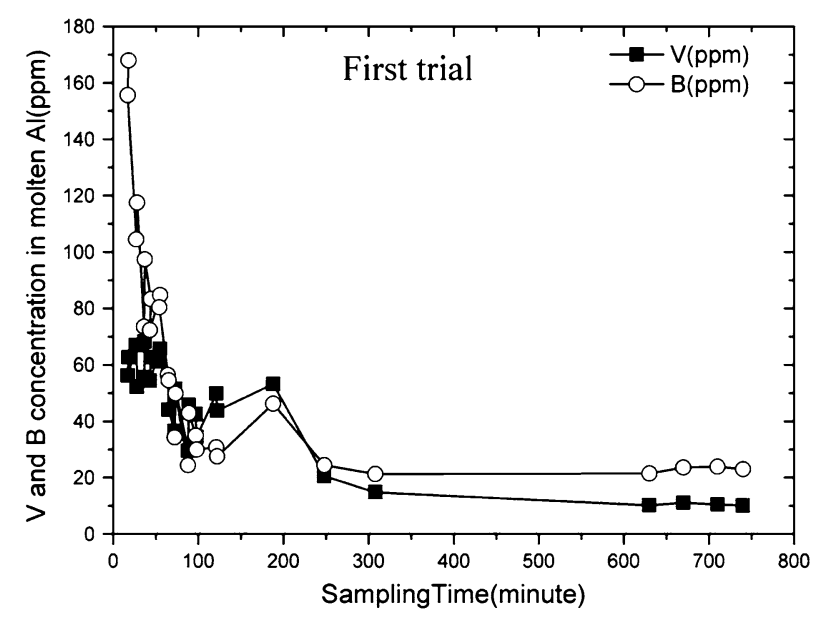

(a)

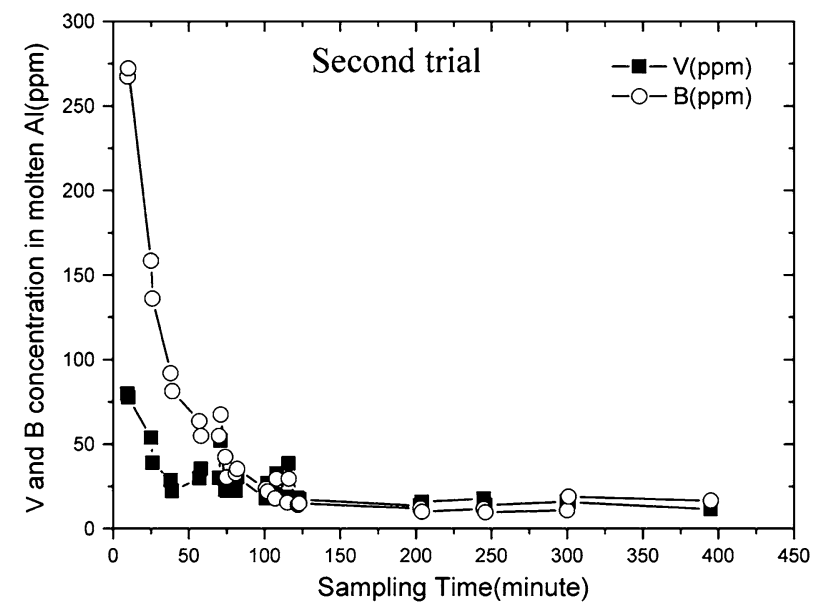

(b)

Fig. 2-The change in concentration ( $\mathrm{ppm}$ ) of $\mathrm{V}$ and $\mathrm{B}$ in molten aluminum in $(a)$ the first and $(b)$ second industrial trials at approximate $T=1023 \mathrm{~K}\left(750{ }^{\circ} \mathrm{C}\right)$.

of their borides within the first hour of treatment when the furnace was being filled.

It can be seen from Figures 2(a) and (b) that the boron concentration was high at the start of process. The sample taken just after the addition of the first crucible into the furnace showed the concentration of $168 \mathrm{ppm}$ boron in the first trial, which is nearly 4 times in excess of the stoichiometric requirements assuming the formation of transition metal diborides. Initially, the melt was supersaturated with $\mathrm{B}$, due to the addition of the Al-8 wt pct $\mathrm{B}\left(\mathrm{AlB}_{12}\right)$ master alloy at the filling stage of furnace.

The percentage removal of $\mathrm{V}$ in the form of $\mathrm{VB}_{2}$ was calculated and is shown in Figure 3. It was observed that 80 pet $\mathrm{V}$ is converted into $\mathrm{VB}_{2}$ during first 300 minutes of boron treatment in the first trial. The removal of $\mathrm{V}$ was insignificant in the later stage of process (after 300 to 728 minutes) as shown in Figure 3.

It has been reported ${ }^{[26]}$ that the reaction of $\mathrm{VB}_{2}$ formation is first order with respect to $\mathrm{V}$ in molten aluminum. Moreover, it has also been reported that the kinetics of reaction was controlled by the mass transfer of $\mathrm{V}$ in liquid phase in the early stage of reaction. In this 


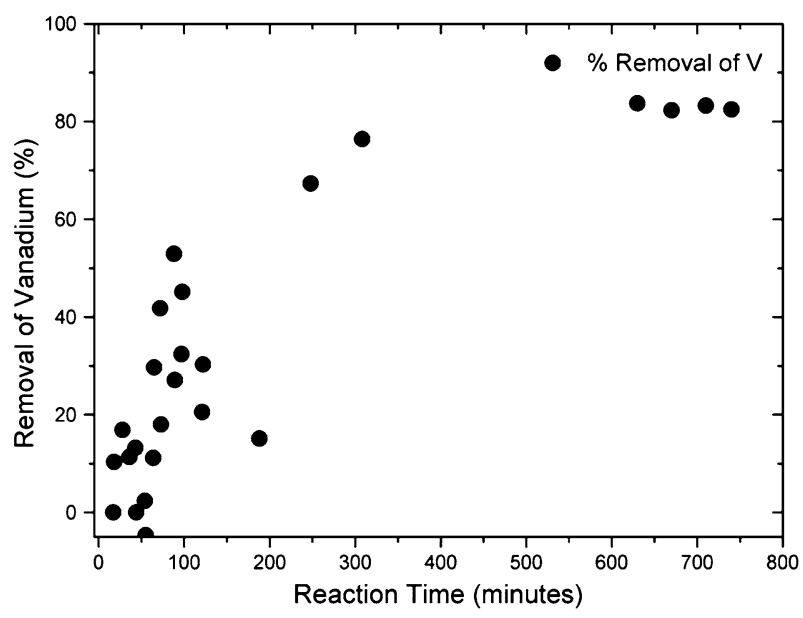

Fig. 3-The percentage removal of $\mathrm{V}$ into borides as a function of time during the first trial.

study, the kinetics of impurities such as $\mathrm{V}$ and $\mathrm{Ti}$ was analyzed using liquid phase mass transfer kinetic model similar to that reported previously. ${ }^{[26]}$ The integrated kinetic equation for liquid phase mass transfer can be written as given in Eq. [1] $]^{[29,30]}$

$$
Y \ln Z=-k t
$$

where $Y=\frac{V_{\mathrm{m}}}{A} \frac{(\text { wt pct TM })_{\mathrm{o}}-(\text { wt pct TM })_{\mathrm{e}}}{(\text { wt pet TM })_{\mathrm{o}}}$ and $Z=$ $\left[\frac{(\text { wt pct TM })-(\text { wt pct TM })_{\mathrm{e}}}{(\text { wt pct TM })_{\mathrm{o}}-(\text { wt pct TM })_{\mathrm{e}}}\right]$

$k, A$, and $V_{\mathrm{m}}$ are the mass transfer coefficient in liquid phase, interfacial area of $\mathrm{AlB}_{12}$ particles and volume of molten alloy, respectively. (wt pct TM), (wt pct TM) and (wt pct TM) are the concentrations of transition metals ( $\mathrm{V}$ and $\mathrm{Ti}$ ) in molten aluminum at time $t$, zero and at equilibrium (predicted by FactSage 6.2).

Equation [1] can also be used for chemical reaction control at the interface of $\mathrm{AlB}_{12}$ particles, with a principal difference of $k$ being the chemical rate constant. One of the important steps to analyze the solidliquid reaction kinetics is the determination of a representative interfacial area. In this case, the interfacial area of $\mathrm{AlB}_{12}$ particles was calculated by SEM image analysis of Al-8 wt pet $\mathrm{B}\left(\mathrm{AlB}_{12}\right)$ ingots added to the furnace. The procedure of estimating initial interfacial area using image processing software (ImageJ, version 1.47 hour) can be found elsewhere. ${ }^{[27]}$ It was difficult to track changes in the $\mathrm{AlB}_{12}$ interfacial area over the period of reaction during industrial boron treatment process. Therefore, it was assumed that the interfacial area and volume remain constant throughout the process. The left hand side of Eq. [1] was plotted against time using the experimental data of $\mathrm{V}$ removal from smelter grade aluminum at $1023 \mathrm{~K}\left(750{ }^{\circ} \mathrm{C}\right)$ and the result is shown in Figure 4. The calculated mass transfer coefficient $\left(k_{\mathrm{m}}\right)$ of $\mathrm{V}$ in aluminum melt was $1.1 \times 10^{-4} \mathrm{~m} / \mathrm{s}$ that is within the range of typical values reported in the literature. ${ }^{[31]}$

The calculated mass transfer coefficient $\left(k_{\mathrm{m}}=1.1 \times\right.$ $10^{-4} \mathrm{~m} / \mathrm{s}$ ) of $\mathrm{V}$ in the melt during industrial trials was

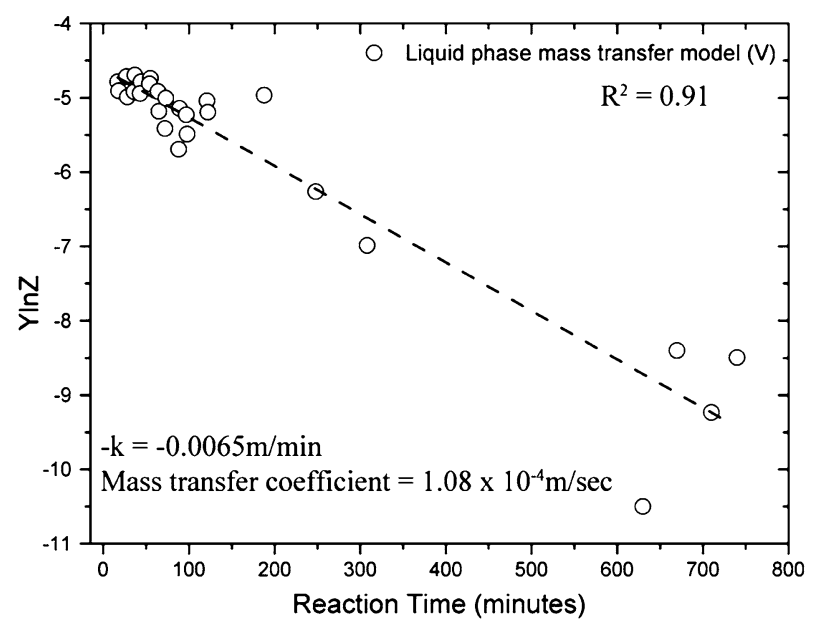

Fig. 4-Integrated rate plot of $\mathrm{V}$ using mass transfer model during first trial at $T=1023 \mathrm{~K}\left(750^{\circ} \mathrm{C}\right)$.

approximately 20 times slower compared to laboratory experiments $k_{\mathrm{m}}=2.2 \times 10^{-3} \mathrm{~m} / \mathrm{s}$, reported in Part II of this paper series. Overall, the mass transfer coefficient in bulk melt depends on the initial concentration of reacting species, level of stirring and the geometry of furnace. Therefore, the possible reasons of slower $\mathrm{V}$ mass transfer in industrial process were the lower initial concentration, the large volume of bulk aluminum melt, and the different flow patterns within the furnace. In the Part II of this paper series, kinetic investigations were conducted using $1 \mathrm{wt}$ pct concentration of $\mathrm{V}$ in molten aluminum alloy. The employed concentration of $\mathrm{V}$ was much higher compared to concentration in industrial practice that is in the range of 100 to $350 \mathrm{ppm}$.

\section{B. Additional Laboratory Studies-the Effect of Initial V Concentration, Induction, and Gas Stirring}

Considering the typical concentration of $\mathrm{V}$ in smelter grade aluminum, additional laboratory studies were conducted with initial $\mathrm{V}$ concentration in molten aluminum of $350 \mathrm{ppm}$. This was carried out to evaluate the effect of lower initial $\mathrm{V}$ concentration and the effect of induction and gas stirring to the mass transfer coefficient. A $1000 \mathrm{~g}$ melt of Al-0.035 wt pet V-0.037 wt pet B was prepared similar to the previous study. ${ }^{[25]}$ The added amount of boron was $250 \mathrm{wt}$ pct excess to the stoichiometry requirement for the formation of $\mathrm{VB}_{2}$.

An induction furnace was used for the additional laboratory studies, and the details has been presented elsewhere. ${ }^{[25]}$ Pure aluminum ingots were melted in a clay-bonded graphite crucible in the furnace. Master alloys (Al-1 wt pc V and Al-8 wt pct B) of appropriate proportion were added into the liquid aluminum at $1023 \mathrm{~K}\left(750^{\circ} \mathrm{C}\right)$. Two sets of experiments were carried out. In one set of experiments, only induction stirring was present. For the second set of experiments, both induction and gas stirrings were applied to the molten alloy, i.e., by injecting Argon gas from top using alumina tube at a flow rate of $1.764 \mathrm{~L} / \mathrm{min}$. Samples were taken from each alloy at different intervals after the addition of master alloys into the aluminum melts, i.e., 


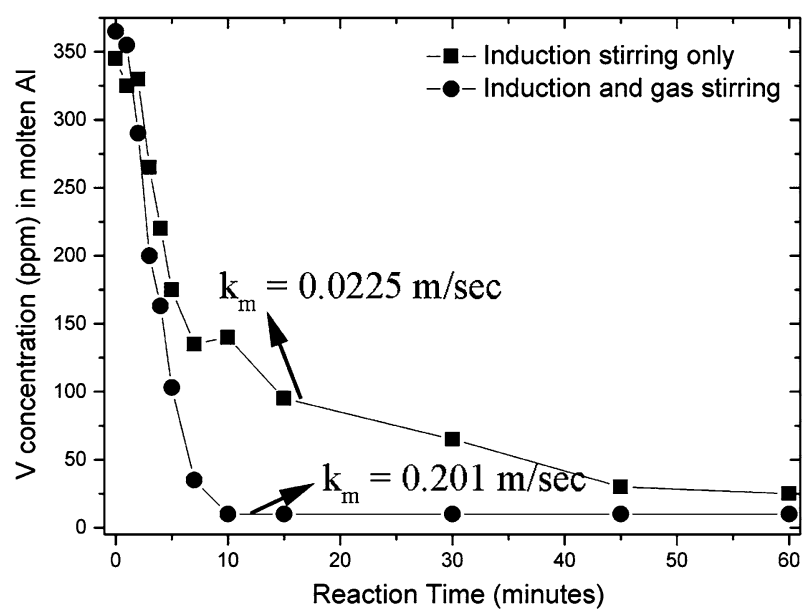

Fig. 5-The change in the concentration of $\mathrm{V}$ in Al-0.0350 wt pet $\mathrm{V}-0.037$ wt pet $\mathrm{B}$ alloys during laboratory trials with induction and both induction and gas stirrings at $1023 \mathrm{~K}\left(750^{\circ} \mathrm{C}\right)$.

at $0,1,2,3,4,5,7,10,15,30,45$, and 60 minutes. The samples were allowed to solidify in the ambient environment.

The changes in $\mathrm{V}$ concentration $v$ s reaction time for the additional laboratory studies are shown in Figure 5. The kinetics of $\mathrm{V}$ removal was fast in the early stage of reaction and became slow with increasing reaction time. In the case of induction stirring only, there was a sudden decrease in the rate at about 10 minutes of reaction. This is similar to the case of experiments with $1 \mathrm{wt}$ pct $\mathrm{V}$, in which the decrease in rate attributed to the formation of solid $\mathrm{VB}_{2}$ layer. ${ }^{[26]}$ In the case of additional stirring using argon gas, the kinetics of $\mathrm{V}$ was further enhanced as shown in Figure 5. The concentration of V dropped to $<10 \mathrm{ppm}$ in the first 10 minutes of reaction and no impediment. Further stirring and holding of melt after this time have no significant effect. This may suggest that in the case of Al-350 ppm V, gas stirring avoids the formation of solid $\mathrm{VB}_{2}$ layer and allows the reaction to complete, similar to the case of Al-1 wt pct $\mathrm{V}$. The calculated mass transfer coefficient $\left(k_{\mathrm{m}}\right)$ for the cases without and with gas stirring was found to be $2.3 \times 10^{-2}$ and $2 \times 10^{-1} \mathrm{~m} / \mathrm{s}$, respectively.

The summary of the measured $k_{\mathrm{m}}$ for different conditions and associated stirring energy is shown in Table II. The detailed calculations of induction and gas stirring have been reported elsewhere. ${ }^{[28]}$ It was observed that mass transfer of $\mathrm{V}$ in molten aluminum enhanced with increasing stirring energy. In the case of lower $\mathrm{V}$ concentration (68 to $350 \mathrm{ppm}$ ), as stirring increased from light mechanical to induction and argon gas purging, the mass transfer was enhanced by more than 1500 times. Similar trend of mass transfer was observed for higher concentration ( $1 \mathrm{wt}$ pct) of $\mathrm{V}$ in molten aluminum. However, the stirring effect was not pronounced compared to the earlier case, which can be attributed due to the formation of $\mathrm{VB}_{2}$ solid product layer. ${ }^{[25,26]}$ It was postulated that the flow patterns generated during induction melting could not break the $\mathrm{VB}_{2}$ solid product layer and consequently, the increase in mass transfer of $\mathrm{V}$ was less than that of the case of gas stirring. It is clear from the results that $k_{\mathrm{m}}$ is a sensitive function of the stirring mechanism and initial $\mathrm{V}$ concentration.

\section{The Kinetics of $\mathrm{Ti}, \mathrm{Zr}, \mathrm{Cr}$, and Fe Removal from Aluminum}

$\mathrm{Ti}, \mathrm{Zr}$, and $\mathrm{Cr}$ were also present and contributed to $33,3.5$, and 3.5 pct of the total transition metal impurities in the smelter grade aluminum used in the industrial trials. The change in the concentration of $\mathrm{Ti}$, $\mathrm{Zr}$, and $\mathrm{Cr}$ in the first and second trials is shown in Figures 6(a) and (b). Two samples were taken at different locations (top and bottom) of the furnace and have different concentration of $\mathrm{Ti}$ that is shown by spikes in Figures 6(a) and (b). The concentration of $\mathrm{Ti}$ decreased from 31 to $2 \mathrm{ppm}$ during the boron treatment process of first trial. The decrease in $\mathrm{Ti}$ concentration was not as fast as $\mathrm{V}$. Moreover, the concentration of $\mathrm{Zr}$ and $\mathrm{Cr}$ only experienced a little change during the boron treatment.

The left hand side of Eq. [1] was plotted against reaction time using Ti experimental data similar to that for V (Section III-A), and is shown in Figure 7. The calculated mass transfer coefficient $\left(k_{\mathrm{m}}\right)$ of Ti in molten aluminum was $2.6 \times 10^{-4} \mathrm{~m} / \mathrm{s}$. It should be noted that the mass transfer coefficients of $\mathrm{Ti}$ are also within the range reported in literature. ${ }^{[31]}$

Further analyses were carried out by comparing the correlations between the transition metals concentration. The correlations between the concentration of $\mathrm{Ti}$ and $\mathrm{V}$ at different reaction times during the first and second trials were plotted and are shown in Figures 8(a) and (b). Linear lines fitting the experimental data gives $R^{2}=0.97$, which shows the best-fit scenario for both trials. It can be concluded from the experimental results shown in Figure 7 that the removal of Ti and $\mathrm{V}$ from $\mathrm{Al}$ into their borides has a linear relationship.

In general, those samples at the top showed higher levels than those taken at the bottom of furnace, indicating a concentration gradient due to the settling of the borides. However, there was a high degree of noise in the data perhaps due to natural convection induced mixing currents in the molten aluminum.

The slope of the line in Figure 8(a) is 0.57 which corresponds to a slope of 0.6 in mol pct (i.e., slope in mol pct $=$ slope in $\mathrm{ppm} \times$ molecular weight of $\mathrm{V}$ divided by molecular weight of $\mathrm{Ti}$ ). For the second trial, the slope of the curve was found to be similar, i.e., 0.59 which corresponds to a slope of 0.63 in mol pct, as shown in Figure 8(b). Since the slopes are less than 1, it could be concluded that the rate of decrease in concentration of $\mathrm{V}$ is higher than that of $\mathrm{Ti}$. It has been predicted through the thermodynamic analysis of $\mathrm{Zr}$, Ti, $\mathrm{V}$, and $\mathrm{Cr}$ impurities in molten aluminum that $\mathrm{ZrB}_{2}$ and $\mathrm{TiB}_{2}$ are more stable than $\mathrm{VB}_{2}$ hence expected to form preferentially. That is $\mathrm{Zr}$ and $\mathrm{Ti}$ would be removed in preference to $\mathrm{V}$ in forming $\mathrm{ZrB}_{2}$ and $\mathrm{TiB}_{2}$ at $1023 \mathrm{~K}$ $\left(750{ }^{\circ} \mathrm{C}\right),{ }^{[17]}$ i.e., the complete removal of $\mathrm{Zr}$ and $\mathrm{Ti}$ would be expected before further $\mathrm{V}$ is removed from the melt. The experimental results shown in Figures 8(a) and (b) clearly show that this was not the case. This also 
Table II. Summary of the Measured $\boldsymbol{k}_{\mathrm{m}}$ for Different Conditions

\begin{tabular}{|c|c|c|c|c|c|c|}
\hline$T\left[\mathrm{~K}\left({ }^{\circ} \mathrm{C}\right)\right]$ & $\begin{array}{c}\text { Type of } \\
\text { Experiment }\end{array}$ & $\begin{array}{l}\text { Initial V } \\
\text { Conc. }\end{array}$ & $\begin{array}{l}\text { Stirring Mechanism } \\
\text { and Period (minutes) }\end{array}$ & $\begin{array}{l}\text { Stirring Energy } \\
\quad\left(\varepsilon^{o}\right)(\mathrm{W} / \mathrm{t})\end{array}$ & $k_{\mathrm{m}}(\mathrm{m} / \mathrm{s})$ & Source \\
\hline $1023(750)$ & plant trials \#1 & $68 \mathrm{ppm}$ & light mechanical (2 $\mathrm{min})$ & $10^{-4}$ to $10^{-5 *}$ & $1.1 \times 10^{-4}$ & this study \\
\hline $1023(750)$ & plant trials \#2 & $80 \mathrm{ppm}$ & light mechanical ( $2 \mathrm{~min})$ & $10^{-4}$ to $10^{-5 *}$ & $1.3 \times 10^{-4}$ & this study \\
\hline $1023(750)$ & laboratory & $350 \mathrm{ppm}$ & induction $(60 \mathrm{~min})$ & $9.32 \times 10^{-2}$ & $2.3 \times 10^{-2}$ & this study \\
\hline $1023(750)$ & laboratory & $350 \mathrm{ppm}$ & induction $+\operatorname{Ar}$ gas $(60 \mathrm{~min})$ & $9.63 \times 10^{-2}$ & $2.00 \times 10^{-1}$ & this study \\
\hline $1023(750)$ & laboratory & $1 \mathrm{wt}$ pct & natural convection (60 $\mathrm{min})$ & $9.72 \times 10^{-6 * *}$ & $2.2 \times 10^{-3}$ & Ref. [27] \\
\hline $1023(750)$ & laboratory & $1 \mathrm{wt}$ pct & induction $(60 \mathrm{~min})$ & $9.32 \times 10^{-2}$ & $6.2 \times 10^{-4}$ & Ref. [26] \\
\hline $1023(750)$ & laboratory & $1 \mathrm{wt}$ pct & $\mathrm{Ar} \operatorname{gas}(10 \mathrm{~min})$ & $3.06 \times 10^{-3}$ & $5.8 \times 10^{-3}$ & Ref. [27] \\
\hline
\end{tabular}

*Estimated values by comparing natural and other stirring mechanisms in this study.

**Calculated using estimated velocity in the melt.

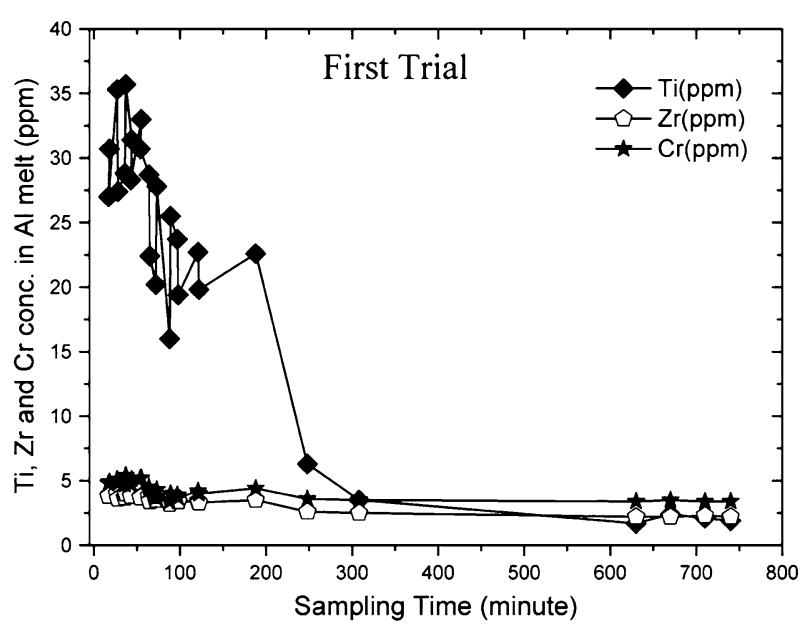

(a)

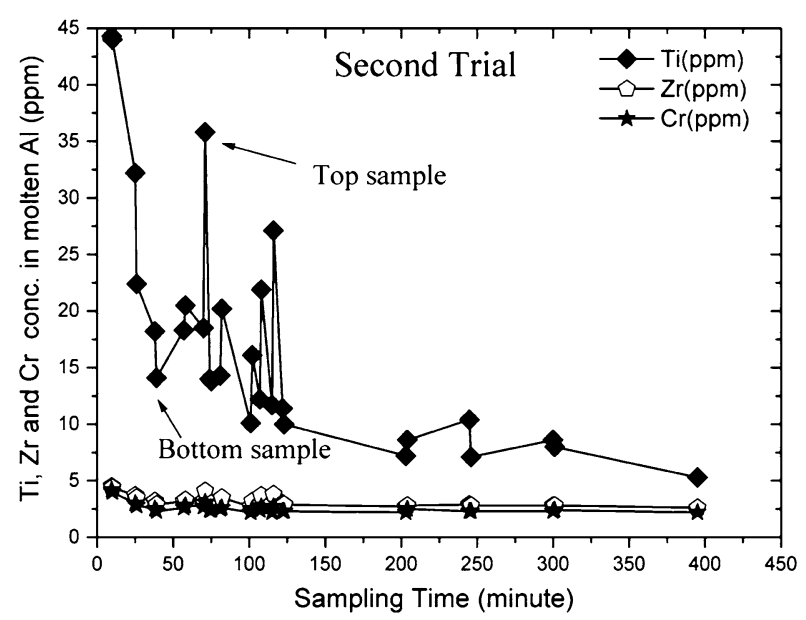

(b)

Fig. 6-The concentration (ppm) of $\mathrm{Ti}, \mathrm{Zr}$, and $\mathrm{Cr}$ impurities in molten aluminum in the first and second industrial trials at $1023 \mathrm{~K}$ $\left(750^{\circ} \mathrm{C}\right)$

suggests that the mechanism for the removal of multiple transition metal impurities is not straight forward. By comparing Figures 2, 6, and 8, it could be concluded that the overall behavior of $\mathrm{V}$ and $\mathrm{Ti}$ is similar during both trials. There is a drastic drop in concentration of both $\mathrm{Ti}$ and $\mathrm{V}$ in the early stage of boron treatment that becomes insignificant with reaction time. The overall

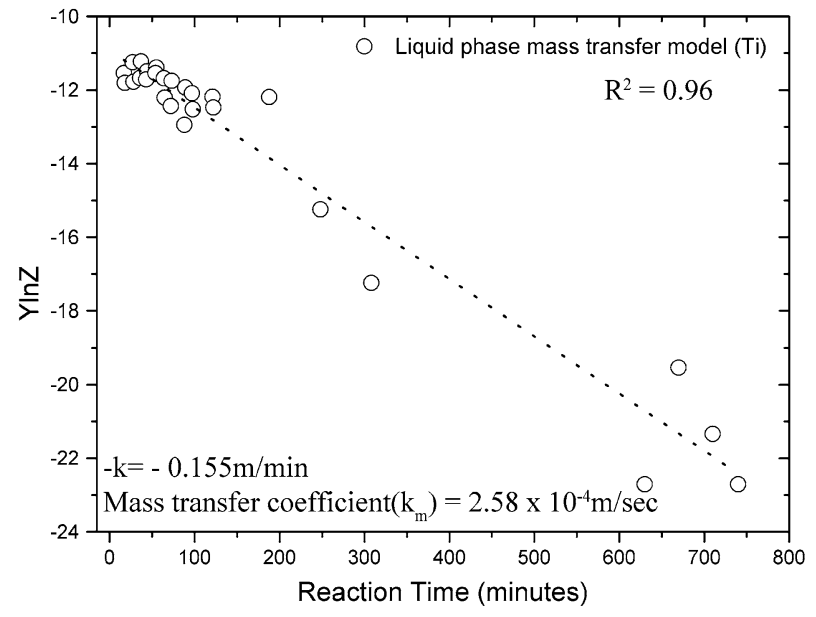

Fig. 7-Integrated rate plot of Ti using mass transfer model during first trial at $T=1023 \mathrm{~K}\left(750{ }^{\circ} \mathrm{C}\right)$.

similarity in the kinetic of $\mathrm{V}$ and $\mathrm{Ti}$ could be justified with similar mass transfer coefficients. The calculated mass transfer coefficients for $\mathrm{V}$ and $\mathrm{Ti}$ are within the range reported in literature. ${ }^{[31]}$ Therefore, it could be concluded that the removal of impurities (V, Ti) during boron treatment are controlled by mass transfer in molten aluminum. From the industrial trials, it was found that $\mathrm{V}$ was removed faster than $\mathrm{Ti}$ because of higher initial concentration/driving force, and the concentration of $\mathrm{Zr}$ and $\mathrm{Cr}$ was not changed much. This behavior can be understood as the followings:

1. The driving force (concentration difference) for the reaction of $\mathrm{VB}_{2}$ formation is bigger as the concentration of $\mathrm{V}$ in $\mathrm{Al}$ melt is much higher compared to Ti. The dependence of the overall kinetic on the concentration difference also supports the notion that the process is controlled by mass transfer.

2. It is possible that the overall kinetics of $\mathrm{TiB}_{2}$ formation was slower (i.e., kinetically limited) than $\mathrm{VB}_{2}$ in molten aluminum

This also suggests that in the system studied, complex $\mathrm{VB}_{2}-\mathrm{TiB}_{2}$ clusters were formed (regardless whether they are in the form of solid solution or just physical clustering) rather than sequential formation of each boride as both $\mathrm{V}$ and $\mathrm{Ti}$ concentrations in the melt decreased at the same time. 


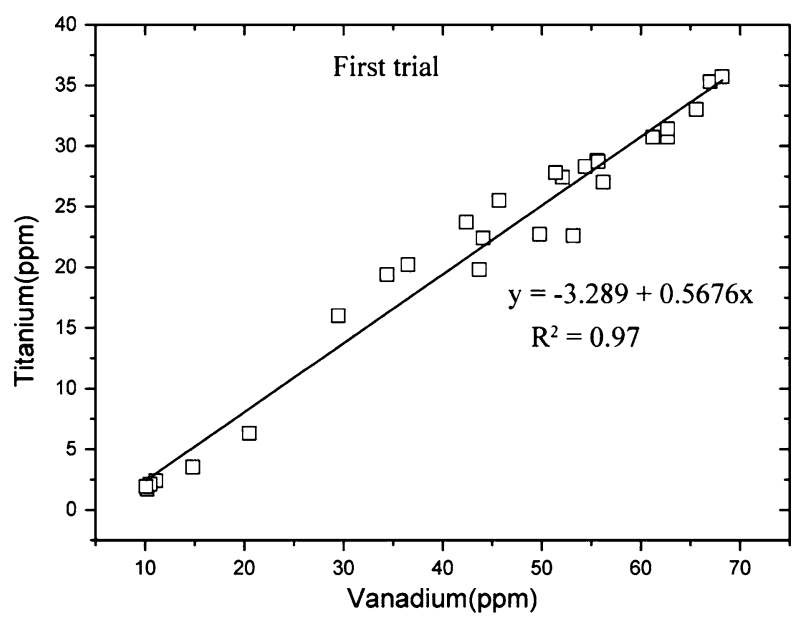

(a)

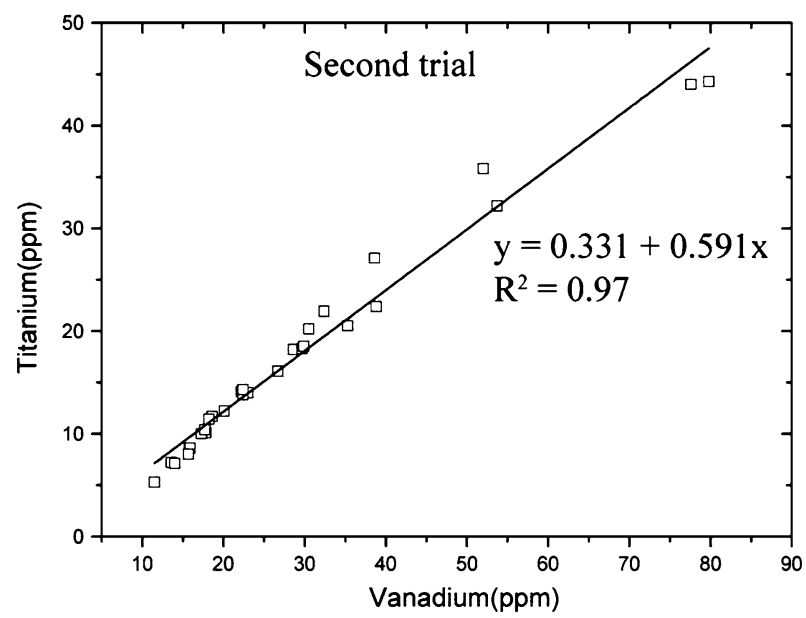

(b)

Fig. 8-The relationship between the concentration of $\mathrm{Ti}$ and $\mathrm{V}$ at various reaction times, at $1023 \mathrm{~K}\left(750{ }^{\circ} \mathrm{C}\right)$ for $(a)$ first and $(b)$ second trials.

The removal of non-reactive impurities in aluminum such as $\mathrm{Fe}$ and $\mathrm{Ni}$ are of a great challenge to researchers. ${ }^{[22,23,32,33]}$ The removal of high concentration of $\mathrm{Fe}$ from molten aluminum using borates was investigated by Gao et al. ${ }^{[14]}$ It was reported that the minimum level of $\mathrm{Fe}$ that could be achieved using borate additives in molten aluminum is $11.9 \mathrm{wt}$ pct. This level of Fe concentration is much higher than the particular situation under investigation (ppm level). To investigate the effect of boron treatment to $\mathrm{Fe}$ (exist in solute concentrations) in $\mathrm{Al}$, the concentrations of $\mathrm{Fe}, \mathrm{V}$, and $\mathrm{B}$ from the first trial were plotted in one graph and are given in Figure 9.

It can be seen that the concentration of $\mathrm{Fe}$ decreased initially, then increased and remain unchanged when the melt was held for longer time. There seemed to be no direct correlations between the change in the $\mathrm{Fe}$ and $\mathrm{B}$ concentrations. This result suggests that low concentration of $\mathrm{Fe}$ cannot be removed by boron treatment, i.e., through the addition of Al-B master alloys, as shown in Figure 9. The variation of $\mathrm{Fe}$ concentration could just be due to the dynamics of flow inside the furnace after each crucible filling that has different Fe level. The

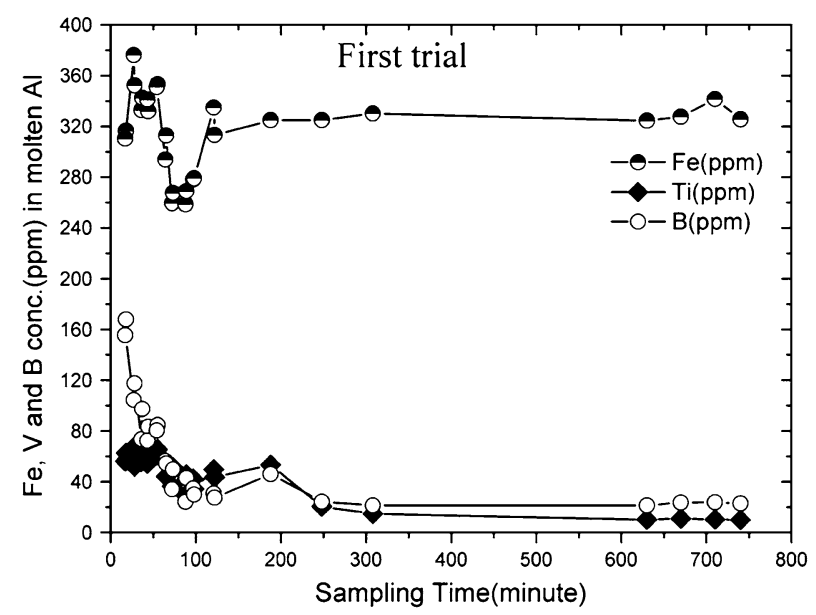

Fig. 9- The change in the concentrations of $\mathrm{V}, \mathrm{Fe}$, and $\mathrm{B}$ during the first trial at $1023 \mathrm{~K}\left(750^{\circ} \mathrm{C}\right)$.

change in the concentration of $\mathrm{Fe}$ during the boron treatment of molten aluminum in the second trial was similar to the first, thus not reproduced here.

\section{Mass Balance Analysis}

The compositional analysis of $\mathrm{V}, \mathrm{Ti}, \mathrm{Zr}, \mathrm{Cr}$, and $\mathrm{B}$ was carried out for both trials, and the results are summarized in Table III. The mass balance analysis revealed that 84 pct V and 94 pct Ti were removed from molten aluminum during the first trial of boron treatment. The starting concentration of $\mathrm{Zr}$ and $\mathrm{Cr}$ was much less than $\mathrm{V}$ and $\mathrm{Ti}$, and their overall removal was only 44 and 31 pct. Comparable results were obtained for the second trial, and these are also shown in Table III.

The mass balance of boron, the initial and the final total concentrations of $\mathrm{V}, \mathrm{Ti}, \mathrm{Zr}$, and $\mathrm{Cr}$ are shown in Table IV. The stoichiometric requirements of boron were calculated assuming the formation of $\mathrm{VB}_{2}, \mathrm{TiB}_{2}$, $\mathrm{ZrB}_{2}$, and $\mathrm{CrB}_{2}$. The boron additions were 35 pct in excess and 24 pct in deficit in the first and second trials, respectively. The melt was held for a longer period (740 minutes) in the first trial. It can be seen from the results that there were residual impurities present after both trials. The concentration of the remaining impurities in the case of the first trial was lesser, but only by a small difference compared to those from the second trial, i.e., $4 \mathrm{ppm}$. Therefore, there is a potential for the improvement of the boron treatment by minimizing the amount of excess boron added, reducing the holding time and optimizing the stirring.

\section{E. Inclusions Analysis}

The samples taken from both trials were analyzed using scanning electron microscopy (SEM) for further investigation of inclusions morphology in aluminum matrix. The composition of the inclusions was determined using EDX spectroscopy technique. The SEM secondary electron (SE) images of samples taken at 9 and 82 minutes from second trial are shown in Figure 10. Black particles, with morphology similar to those shown in Figure 1, were 
Table III. The Change in Concentration and Pct Removal of $\mathrm{V}, \mathrm{Ti}, \mathrm{Zr}$, and $\mathrm{V}$ During Trials

\begin{tabular}{|c|c|c|c|c|c|c|}
\hline \multirow[b]{3}{*}{ Impurities } & \multicolumn{3}{|c|}{ First trial } & \multicolumn{3}{|c|}{ Second Trial } \\
\hline & \multicolumn{2}{|c|}{ Conc. (ppm) } & \multirow[b]{2}{*}{ Pct Removal } & \multicolumn{2}{|c|}{ Conc. (ppm) } & \multirow[b]{2}{*}{ Pct Remova } \\
\hline & Start & End & & Start & End & \\
\hline V & 62.7 & 10.1 & 84 & 80 & 11.5 & 86 \\
\hline $\mathrm{Ti}$ & 30.7 & 2 & 94 & 44.3 & 5.3 & 88 \\
\hline $\mathrm{Zr}$ & 3.9 & 2.2 & 44 & 4.5 & 2.6 & 42 \\
\hline $\mathrm{Cr}$ & 4.9 & 3.4 & 31 & 4.2 & 2.2 & 48 \\
\hline B & 168 & 23 & 86 & 267 & 16.6 & 94 \\
\hline
\end{tabular}

Table IV. Mass Analysis of Boron in First and Second Trials

\begin{tabular}{|c|c|c|c|c|c|c|c|}
\hline Trials & $\begin{array}{c}\text { Total TM } \\
\text { Impurities (ppm) }\end{array}$ & $\begin{array}{c}\text { Stoic. Req. } \\
\text { of B (Assuming } \\
\text { Diborides) (kg) }\end{array}$ & $\begin{array}{l}\text { Actual Addition } \\
\text { of } \mathrm{B}(\mathrm{kg})\end{array}$ & $\begin{array}{c}\text { B Excess/ } \\
\text { Deficit (wt pct) }\end{array}$ & $\begin{array}{l}\text { B Remained } \\
\text { in } \mathrm{Al}(\mathrm{kg})\end{array}$ & $\begin{array}{c}\text { Total TM } \\
\text { Impurities } \\
\text { Remained (ppm) }\end{array}$ & $\begin{array}{l}\text { Holding } \\
\text { Time (min) }\end{array}$ \\
\hline First & 102.2 & 2.17 & 3.36 & +35.42 & 1.151 & 17.6 & 740 \\
\hline Second & 133.0 & 2.84 & 2.16 & -23.94 & 0.830 & 21.6 & 395 \\
\hline
\end{tabular}

The signs $(-)$ and $(+)$ represent boron deficit and excess, respectively,.

$T M$, transition metal impurities such $\mathrm{V}, \mathrm{Ti}, \mathrm{Zr}$, and $\mathrm{Cr}$.

observed in the 9 minutes sample. EDX analysis was carried out on the black inclusions, and the result is shown in Figure 11(a). The result suggested the presence of $\mathrm{Al}$ and $\mathrm{B}$ and the semi-quantitative analysis suggested $\mathrm{AlB}_{12}$ rather than $\mathrm{AlB}_{2}$ phase. Considering this and the morphology, the inclusions were concluded to be undissolved $\mathrm{AlB}_{12}$, which were initially added to the melt as a source of boron in the form of an Al-B master alloy. The solid $\mathrm{AlB}_{12}$ in the Al-B master alloy was dissolving during the course of time to release boron, which would react with transition metal impurities in molten aluminum. As the reaction proceeds, more boron dissolves and the average size of the $\mathrm{AlB}_{12}$ decreases. This can be seen in the Figure 10(b), which shows inclusions with smaller size $(<10 \mu \mathrm{m})$ at 82 minutes of reaction. In addition of the small boride inclusions, other oxide inclusion was observed. An EDX spectrum of selected inclusion from the 82 min sample is shown in Figure 11(b). The composition analysis showed the presence of $\mathrm{Al}, \mathrm{Si}$, and $\mathrm{O}$, with approximate composition of 26 at. pet Al, 53 at. pet $\mathrm{O}$ and 21 pet $\mathrm{Si}$ (all in atomic pet), thus concluded to be oxides of $\mathrm{Al}$ and $\mathrm{Si}$ $\left(\mathrm{Al}_{2} \mathrm{O}_{3}\right.$ and $\left.\mathrm{SiO}_{2}\right)$. This exogenous inclusion was probably coming from the refractory during the processing and handling of molten metal.

It is worth noticing that transition metal borides inclusions were not detected during the SEM/EDX analyses. It was quite difficult to locate borides of transition metal impurities due to their low concentration in the molten aluminum. It was also likely that the heavier transition metal borides were already settled at the bottom of the furnace during holding of the melt.

\section{IMPLICATIONS TO INDUSTRIAL PRACTICE}

Based on the analyses of the laboratory investigations, including from the previous studies, ${ }^{[26,27]}$ and the industrial trials at aluminum smelter, the followings can be considered for the optimization of industrial boron treatment process:

- By changing the source of boron, the melt treatment time can be optimized. Master alloys having an $\mathrm{AlB}_{2}$ phase are reactive due to the availability of a large interfacial area for reaction with transition metal impurities but slower in the settling of the borides. A shorter melt holding time can be managed by using an Al-B master alloy with the comparatively larger $\mathrm{AlB}_{12}$ particles. In this case, higher concentration of unreacted $\mathrm{AlB}_{12}$ could be expected. Therefore, there is a trade-off between melt holding time and the consumption of Al-B master alloy. Based on the priorities of the casthouse and its economy, an optimized boron treatment process can be developed. Therefore, Al-B master alloys should be used in consultation with suppliers for detailed Al-borides composition to meet the required level of recovery, hence the purity of the final alloy.

- The addition of boron should be carried out in multiple stages. The practice of adding the full quantity of Al-B master alloy at the beginning of process will likely increase the unreacted aluminum borides content. Moreover, there will be a possibility that the larger particles of $\mathrm{Al}-\mathrm{B}\left(\mathrm{AlB}_{12}\right)$ will settle at the bottom of the furnace with limited reaction. The addition of Al-B master alloy in two or three stages during the charging of the furnace will be helpful in maximizing the boron content from the Al-B master alloy.

- Better stirring of the melt will help to redistribute the impurities. Stirring with smooth flow patterns will have less effect compared to intermittent gas injection as described in Part II. ${ }^{[27]}$ Injection of neutral/ inert gas (at least once during the treatment) will help to redistribute and break the solid shells of the transition metal borides around $\mathrm{AlB}_{12} / \mathrm{AlB}_{2}$, as 

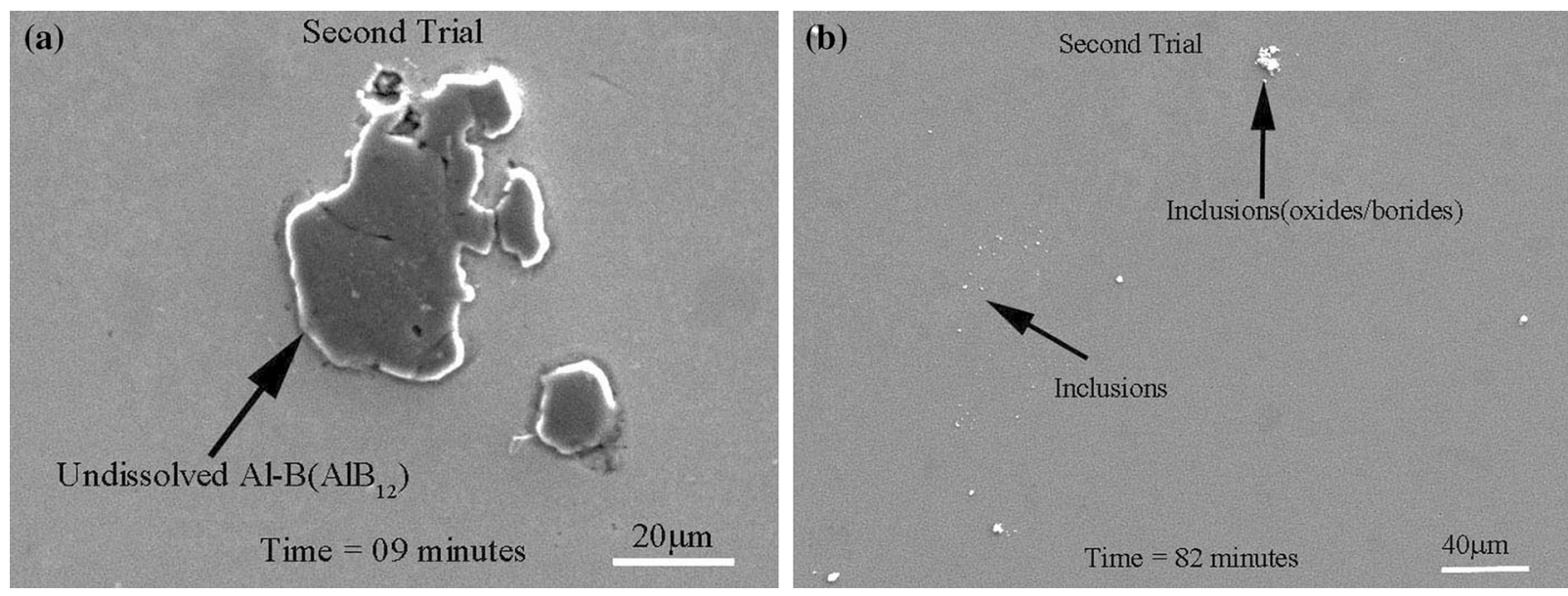

Fig. 10-SEM-SE image of the samples taken after $(a) 9$ and $(b) 82$ min after the addition of Al-8 wt pct B master alloy from the second trial.

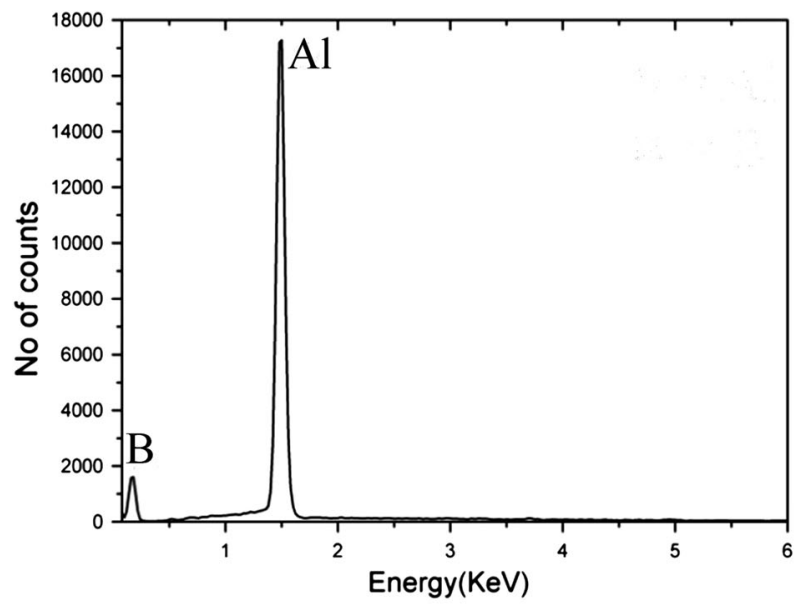

(a)

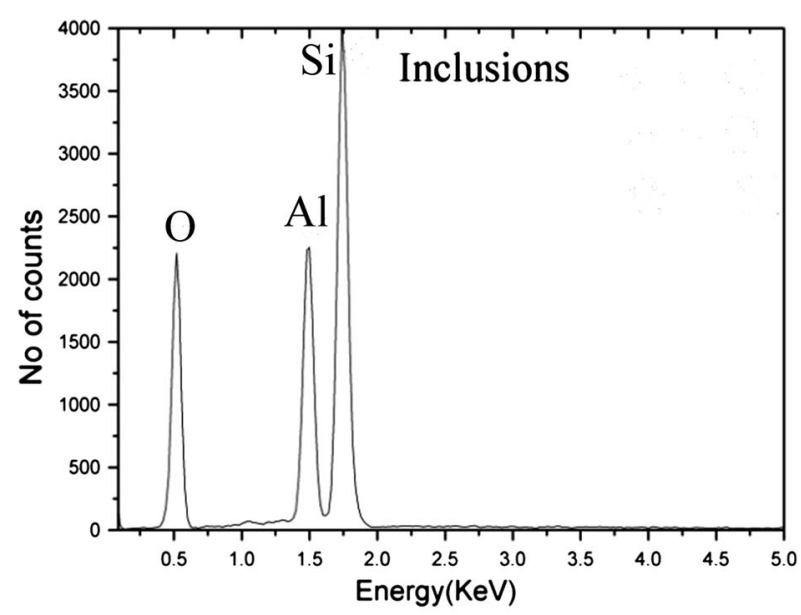

(b)

Fig. 11-EDX analyses of inclusions in samples taken after (a) 9 and (b) $82 \mathrm{~min}$ from the second trial.

described in Part I. ${ }^{[26]}$ The gas bubbling will most likely enhance the mechanism of inclusions removal through floatation. Smaller borides could be removed by the application of appropriate filters available in industry.

\section{CONCLUSIONS}

It was realized that electrical grade aluminum producers have developed their own practices for the removal of transition metal impurities depending on the quality of the final product and casthouse capabilities, but there is no agreed strategy across industry. Different melt holding practices are carried out depending on the final concentration of inclusions and impurities based on the customer requirements. A longer holding time is required to produce a high quality product that has a minimum level of impurities as well as inclusions.

From the kinetics studies of industrial trials, the result suggests that the transition metal impurities removal was controlled by the mass transfer in bulk melt. The calculated mass transfer coefficients $\left(k_{\mathrm{m}}\right)$ of $\mathrm{V}$ and $\mathrm{Ti}$ in the Al melt were $1.1 \times 10^{-4}$ and $2.6 \times 10^{-4} \mathrm{~m} / \mathrm{s}$, respectively. The kinetics analyses of both trials suggested a linear relation between the removal of $\mathrm{V}$ and $\mathrm{Ti}$ from smelter grade aluminum. It was observed that 70 pct $\mathrm{V}$ and $\mathrm{Ti}$ were removed in the first hours of boron treatment. The remaining 15 pct to 20 pct were removed in approximately 11 hours. It was calculated that approximately 26 pct boron was left un-reacted in the end molten alloy that could be minimized by optimizing the current treatment process. The results showed that $\mathrm{Fe}$ and $\mathrm{Ni}$ were not removed during both trials that are also a challenge for high purity aluminum producers.

The SEM analysis of early stage samples showed undissolved $\mathrm{AlB}_{12}$ particles, however, no ring of $\mathrm{VB}_{2} /$ $\mathrm{TiB}_{2}$ was observed. Transition metal borides were not observed during microscopy analyses that may be due to low concentrations of borides in the molten aluminum. $\mathrm{SEM} / \mathrm{EDX}$ analyses detect oxides of $\mathrm{Al}, \mathrm{Si}$ in the polished aluminum samples.

The boron treatment processes can be more economical if the consumption of Al-B master alloys is reduced, that can be achieved by adding Al-B master alloy in 
multiple stages. Moreover, a better stirring of the melt with intermittent gas injection will further improve the reaction time by breaking any boride rings, and also by improving the mass transfer of impurities. It can be concluded that the boron treatment of smelter grade aluminum should have a standard procedure, providing guidelines for electrical grade Al manufacturers.

\section{REFERENCES}

1. G.G. Gauthier: J. Inst. Met., 1936, vol. 59, pp. 129-150.

2. W.A. Dean: Aluminum, 1967, vol. 1, p. 174.

3. K. Grjotheim, C. Krohn, M. Malinovsky, K. Matiasovsky, and J. Thonstad: Aluminum Electrolysis: Fundamentals of the Hall Heroult Process, 2nd ed., Aluminium-Verlag GmbH, Dusseldorf, 1982.

4. J.B. Metson, D.S. Wong, J.H. Hung, and M.P. Taylor: TMS Light Metals, TMS, Warrendale, PA, 2013, pp. 9-13.

5. S.J. Lindsay: TMS Light Metals, TMS, Warrendale, PA, 2013, pp. 5-8.

6. S. Karabay and I. Uzman: Mater. Manuf. Process., 2005, vol. 20, pp. 231-43.

7. G. Dube: European Patent No: 0112024, 1983.

8. W. Stiller and T. Ingenlath: Aluminium (Engl. Ed.), 1984, vol. 60(9), pp. 577-80.

9. W.C. Setzer and G.W. Boone: TMS Light Met., 1991, vol. 1992, pp. $837-44$.

10. P.S. Cooper and M.A. Kearns: ICAA5, 1996, vol. 217, p. 141-46.

11. R. Cook, M.A. Kearns, and P.S. Cooper: TMS Light Metals, TMS, Warrendale, PA, 1997, pp. 809-14.

12. S. Karabay and I. Uzman: J. Mater. Sci. Technol., 2005, vol. 160 (2), pp. 174-82.

13. J.W. Gao, D. Shu, J. Wang, and B.D. Sun: Scripta Mater., 2007, vol. 57 , pp. $197-200$

14. J.W. Gao, D. Shu, J. Wang, and B.D. Sun: J. Mater. Sci. Technol., 2009, vol. 25 , pp. $1462-66$.

15. J.W. Gao, D. Shu, J. Wang, and B.D. Sun: J. Mater. Sci. Technol., 2009 , vol. 25 , pp. $619-24$.
16. A. Khaliq, M.A. Rhamdhani, G. Brooks, J. Grandfield, J. Mitchell, and D. Cameron: Proc. EMC (Eur. Metall. Conf.), 2011, pp. 825-38.

17. A. Khaliq, M.A. Rhamdhani, G. Brooks, and J. Grandfield: TMS Light Metals, TMS, Warrendale, PA, 2011, pp. 751-56.

18. G.Q. Wang, S.H. Liu, C.M. Li, and Q. Gao: Trans. Nonferrous Met. Soc., 2002, vol. 12 (6), pp. 1112-16.

19. F. Vogt, R. Tonti, M. Hunt, and L. Edwards: TMS Light Metals, TMS, Warrendale, PA, 2004, pp. 489-93.

20. K.D. Bartholomew: TMS Light Metals, TMS, Warrendale, PA, 2013, pp. 15-20.

21. C. Coney, L. Crabtree, J. Gavin, W. Marcrum, A. Weber, and L. Edwards: TMS Light Metals, TMS, Warrendale, PA, 2013, pp. 21-25.

22. J.F. Grandfield and J.A. Taylor: TMS Light Metals, TMS, Warrendale, PA, 2009, pp. 1007-11.

23. M.A. Rhamdhani, J.F. Grandfield, A. Khaliq, and G. Brooks: TMS Light Metals, TMS, Warrendale, PA, 2013, pp. 33-38.

24. J.F. Grandfield, L. Sweet, C. Davidson, J. Mitchell, A. Beer, S. Zhu, X. Chen, and M. Easton: TMS Light Metals, TMS, Warrendale, PA, 2013, pp. 38-45.

25. A. Khaliq, M.A. Rhamdhani, G. Brooks, and J. Grandfield: Metall. Mater. Trans. B, 2013, DOI:10.1007/s11663-013-9974-x.

26. A. Khaliq, M.A. Rhamdhani, G. Brooks, and J. Grandfield: Metall. Mater. Trans. B, 2013, DOI:10.1007/s11663-013-9975-9.

27. A. Khaliq: PhD Thesis, Swinburne University of Technology, Melbourne, 2013.

28. C.J. Simensen and G. Strand: J. Anal. Chem., 1981, vol. 308 (1), pp. 11-16.

29. R.J. Pomfret and P. Grievson: Can. Metall. Q., 1983, vol. 22, pp. 287-99.

30. M.A. Rhamdhani, G.A. Brooks, and K.S. Coley: Metall. Mater. Trans. B, 2005, vol. 36B, pp. 219-27.

31. R.I.L. Guthrie: Engineering in Process Metallurgy, Clarendon Press, Oxford, 1992

32. D.R. Poirier and G.H. Geiger: Transport Phenomena in Materials Processing, Minerals, Metals \& Materials Society, Warrendale, PA, 1994.

33. M.A. Dewan, M.A. Rhamdhani, J.B. Mitchell, C.J. Davidson, G.A. Brooks, M. Easton, and J.F. Grandfield: Mater. Sci. Forum, 2011, vol. 693, pp. 149-60. 